\title{
Sida acuta Burm. f.: a medicinal plant with numerous potencies
}

\author{
Simplice Damintoti Karou ${ }^{1,3 *}$, Wendyam MC Nadembega ${ }^{1,2}$, Denise P Ilboudo ${ }^{1,2}$, Djeneba \\ Ouermi $^{1,2}$, Messanvi Gbeassor ${ }^{3}$, Comlan De Souza ${ }^{3}$ and Jacques Simpore ${ }^{1,2}$ \\ ${ }^{1}$ Centre de Recherche Biomoléculaire Pietro Annigoni (CERBA) 01 BP 444 Ouagadougou 01, Burkina Faso. \\ ${ }^{2}$ UFR/SVT, Université de Ouagadougou 03 BP 7021 Ouagadougou 03; Burkina Faso. \\ ${ }^{3}$ Faculté des Sciences, Université de Lomé, BP 1515, Lomé, Togo.
}

Accepted 12 November, 2007

\begin{abstract}
Sida acuta is shrub belonging to Malvaceae family. The plant is widely distributed in the subtropical regions where it is found in bushes, in farms and around habitations. Surveys conducted in indigenous places revealed that the plant had many traditional usages that varied from one region to another. The most cited illnesses are fever, headache and infections diseases. Indeed, many laboratory screening have been conducted to show the scientific rationale behind these usages and many compounds have been isolated from the plant. In the present review we listed the plant usages in folk medicine in some regions where the plant grows and we discussed on the confirmed in vitro activities after laboratory screenings. The review ended with the pharmacological properties of several compounds isolated from S. acuta principally alkaloids.
\end{abstract}

Key words: Ethnomedicine, medicinal plants, natural substances.

\section{INTRODUCTION}

Sida acuta is a malvaceous weed that frequently dominates improved pastures, waste and disturbed places roadsides (Mann et al., 2003). The plant is native to Mexico and Central America but has spread throughout the tropics and subtropics (Holm et al., 1977). In traditional medicine, the plant is often assumed to treat diseases such as fever, headache, skin diseases, diarrhea, and dysentery. Referring to the traditional knowledge, studies have been carried out to confirm the activities the plant is assumed to exert in vivo. The described pharmacological properties of the plants involve the antiplasmodial, antimicrobial, antioxidant, cytotoxic activities and many other properties. Some studies resulted in the isolation of single compounds while the others just demonstrated the activity of the crude extracts. The present review is focused on the traditional usages of the plant, the in vitro laboratory screening results and the pharmacological properties of some compounds isolated from the plant.

*Corresponding author. Email: damin.karou@univ-ouaga.bf or simplicekarou@hotmail.com.

\section{TRADITIONAL USAGES}

S. acuta is widely distributed in pantropical areas and is widely used as traditional medicine in many cases. The plant is also used for spiritual practices. Table 1 displays the traditional usages of the plant in some regions where it grows. Among illnesses the plant is used to cure, fever is the most cited. The administration may be by oral route for example in the case of fever or by external application of the paste directly on the skin for skin diseases or snake bites (Kerharo and Adam, 1974). The plant may be used alone or in combination with other plants according to the diseases or to the healers.

\section{IN VITRO ACTIVITIES AND ISOLATED COMPOUNDS OF SIDA ACUTA}

Isolated compounds of the plant

Several phytochemical screenings resulted in the isolation of various compounds from the plant involving alkaloids and steroidal compounds (Cao and Qi, 1993; 
Table 1. Traditional usages of Sida acuta in several regions.

\begin{tabular}{|c|c|c|c|c|}
\hline Locality & Local name & Used part & Traditional usages & Reference \\
\hline $\begin{array}{l}\text { Guatemala, } \\
\text { Nicaragua }\end{array}$ & - & WP & $\begin{array}{l}\text { Asthma, renal inflammation, colds, } \\
\text { fever, headache, ulcers and worms }\end{array}$ & $\begin{array}{l}\text { (Caceres et al., 1987 ; } \\
\text { Coee and Anderson, 1996) }\end{array}$ \\
\hline Kenya (Digo) & Mbundugo & WP & $\begin{array}{l}\text { The plant is used to prepare } \\
\text { "Bundugo", a supplementary strength } \\
\text { magically added to a person }\end{array}$ & (Pakia, 2005) \\
\hline Nigeria & Iseketu & WP, L & $\begin{array}{l}\text { malaria, ulcer, fever, gonorrhea, } \\
\text { abortion, breast cancer, poisoning, } \\
\text { inflammation, feed for livestock, stops } \\
\text { bleeding, treatment of sores wounds } \\
\text { antipyretic }\end{array}$ & $\begin{array}{l}\text { (Kayode, 2006; Edeoga et } \\
\text { al., 2005 Saganuwan and } \\
\text { Gulumbe, 2006) }\end{array}$ \\
\hline Western Colombia & - & WP & Snakebites & (Otero et al., 2000) \\
\hline Sri Lanka & - & $\mathrm{R}, \mathrm{L}$ & $\begin{array}{l}\text { Hemorrhoids, fevers, impotency, } \\
\text { gonorrhea, and rheumatism. In } \\
\text { mixture as aphrodisiac and for boils } \\
\text { and eye cataracts }\end{array}$ & $\begin{array}{l}\text { (Dash, 1991; Pal and Jain, } \\
\text { 1998) }\end{array}$ \\
\hline $\begin{array}{l}\text { Burkina Faso (Mossi } \\
\text { Central Plate) }\end{array}$ & Zon-Raaga & WP & $\begin{array}{l}\text { Fever, diarrhea, pulmonary affection, } \\
\text { snakebites, insects' bites. Paste of } \\
\text { leaves mixed with salt is applied on } \\
\text { skin to cure panaris }\end{array}$ & $\begin{array}{l}\text { (Nacoulma/Ouedraogo, } \\
\text { 1996) }\end{array}$ \\
\hline
\end{tabular}

-: non available data, L: leaves, R: roots, WP: whole plant.

Dinan et al., 2001). Figure 1 lists the chemical structure of some. The alkaloids occurring in the plant belong to the indoloquinolines family. The main alkaloids are cryptolepine and its derivatives such as quindoline, quindolinone, cryptolepinone and 11-methoxy-quindoline (Jang et al., 2003). The major steroids of the plant are ecdysterone, beta-sistosterol, stigmaterol, ampesterol. Phenolic compounds such as evofolin-A, and B, scopoletin vomifoliol, loliolid and 4-ketopinoresinol have also been isolated (Jang et al., 2003).

\section{Antiplasmodial activity}

The in vitro antiplasmodial activity of the plant was first reported by Karou et al. (2003). The test was performed on fresh clinical isolates of Plasmodium falciparum using the in vitro semi microtest by light microscopy as described by Le Bras and Deloron (1983). Ethanolic extract of the plant was tested both with ethanolic extract of four other plants. As $S$. acuta was the most active plant of the study $\left(\mathrm{IC}_{50}\right.$ value of $\left.4.37 \mu \mathrm{g} / \mathrm{mL}\right)$, its extract was brought under liquid-liquid separation between petroleum ether, chloroform and water resulting in three fractions.
These fractions tested on the parasites revealed that the chloroformic fraction and the aqueous fraction had similar activities while the ether fraction was devoid of intrinsic antiplasmodial activity. This suggested that alkaloids of the plant may be responsible for the activity. The issue of the study confirmed that the activity of the plant was related to its alkaloids which displayed $\mathrm{IC}_{50}$ value of 0.05 $\mu \mathrm{L} / \mathrm{mg}$. Banzouzi et al. (2004) continued the work in the same way using one reference strain of $P$. falciparum: FcM29-Cameroon (chloroquine-resistant strain) and a Nigerian chloroquine-sensitive strain. The antiplasmodial assay was performed with ethanolic and aqueous extract by flow cytometry with incorporation of $\left[{ }^{3} \mathrm{H}\right]$ hypoxanthine (Desjardins et al., 1979; Schulze et al., 1997). The ethanolic extract showed good activity on the two strains with $I_{50}$ values between 3.9 and $5.4 \mu \mathrm{g} / \mathrm{mL}$. The purification of this active extract led to the identification of cryptolepine as the antimalarial agent of the plant.

It is evidence that the plant showed a good in vitro antimalarial activity related to its alkaloid contents. Referring to the traditional practices where the drug is often prepared by boiling plant material in water, this activity may be reduce in vivo since alkaloid solubility in water is $\mathrm{pH}$-dependant. 


\section{Antibacterial activity}

The antimicrobial screening of $S$. acuta revealed that many compounds might be responsible for the activity of the plant. The first antimicrobial screening of the plant was conducted by Anani et al. (2000) using the disk diffusion assay. The authors found that the methanolic extract of the plant had a significant activity on Staphylococcus aureus, Escherichia coli, Bacillus subtilis and Mycobacterium phlei, however the extract was not active on Streptococcus faecalis, Klebsiella pneumoniae, Salmonella thyphimurium, Pseudomonas aeruginosa and Candida albicans. The same findings were confirmed in another study using methanolic extract and similar microorganisms (Rajakaruna et al., 2002). Polyphenols and alkaloids of the plant were tested separately on several pathogenic bacteria including clinical strains and reference strains of Enterobacteriaceae and Staphylococcaceae families. The tests were performed by agar well diffusion (Perez et al., 1990) and the NCCLS (2000) broth microdilution assays. The results revealed that the phenolic compounds had a good in vitro antimicrobial activity and this activity was much influenced by the storage of the extract probably because of the phenolic compounds oxidization. The inhibition zone diameters varied from 11 to $25 \mathrm{~mm}$ for $250 \mu \mathrm{g}$ polyphenols and MBC values ranged from 20 to $2000 \mu \mathrm{g} / \mathrm{mL}$ (Karou et al., 2005). Alkaloids of Sida acuta also displayed a good antibacterial activity. The recorded inhibition zone diameters varied from 16 to $38 \mathrm{~mm}$ for $100 \mu \mathrm{g}$ alkaloids and the MBC values from 80 to $400 \mu \mathrm{g} / \mathrm{mL}$ (Karou et al., 2006). In another study, leaf/flower combination was evaluated for antimicrobial activity using hexane, chloroform, methanol and aqueous extraction methods. The antibacterial activities were exhibited by the four extract on E. coli, S. pyogenes, Pasterella multocida and S. typhimurium as there was no activity exhibited on $S$. typhi, S. pneumoniae and K. pneumoniae (Sanganuwan and Gulumbe, 2006).

As many other plants with antibacterial properties, $S$. acuta contains phenolic compounds that are responsible for the activity of the plant. The current problem with phenolic compounds is the fact that they are vulnerable to polymerization in air through oxidation reactions. This oxidization may first affect the extractability of the phenolic compounds that is crucial in drug preparation; in this topic some authors suggested extracting the compounds directly on fresh material in order to enhance the yield (Scalbert, 1992). However, in our enquiries many traditional healers always dry their plant materials before the use, particularly when the plant does not grow around habitations (Karou et al., 2007). Secondly, an important factor governing the activity of phenolic compounds is their polymerization size. Oxidized condensation of phenols may result in the toxification of microorganisms, while the adverse effects can be observed in some cases (Scalbert, 1991; Field and Lettinga,
1992). Recently in the case of S. acuta we observed that the tested microorganisms were particularly susceptible to the stored extract (Karou et al., 2006). Therefore, it is now the time to think about how to prepare phenolicsbased drugs with traditional healers.

\section{Other in vitro activities}

Since $S$. acuta has several usages in folk medicine it has been involved in many other pharmacological screenings. The plant has been screened for its cancer chemopreventive properties by Jang et al. (2003). The study resulted in the isolation of several compounds, among them quindolinone, cryptolepinone and 11methoxyquindoline was found to induce quinone reductase activity, while cryptolepinone, Ntransferuloyltyramine exhibited a significant inhibition of 7, 12-dimethylbenz-[a]anthracene-induce preneoplastic lesions in mouse mammary organ culture model. These observations suggested that cryptolepinone was a potential chemopreventive agent.

The polyphenol extract of the plant was tested together with polyphenol extract of other medicinal plants for antioxidant activity through free radical scavenging. The tests were performed using the phosphomolybdenum reduction (Prieto et al., 1998) and the ABTS radical cation decolorization assays (Re et al., 1999) with trolox as standard antioxidant. The results showed that there was a good correlation between the two methods $(r=0.9)$ and $S$. acuta had a weak free radical scavenging according to values recorded with bark extracts of $K$. Senegalensis, $P$. erinaceus and $C$. micranthum in the same study. The activities were highly correlated with the total phenolic content determined by the Folin-Ciocalteu reagent (Singleton et al., 1999) with gallic acid as standard $(r=0.94$ and $r=0.91$ with the two assays respectively).

In another study, Otero et al. (2000a, b) showed that the ethanolic extract of the plant had a moderate activity against the lethal effect of Bothrops atrox venom. In Western Kenya where the plant is consumed as legume, a study using Brine shrimp lethality tests revealed that the plant was toxic $\left(\mathrm{LC}_{50}=99.4 \mu \mathrm{g} / \mathrm{ml}\right)$. The author concluded that the plant can cause acute or chronic toxicities when consumed in large quantities or over a long period of time (Orech et al., 2005).

Malairajan et al. (2006) had demonstrated the analgesic properties of the whole plant extract in animal model. The authors conducted the tests using two methods the hot plate method described by Woolfe and Mac Donalds (1944) and the tail immersion method described by Dykstra and Woods (1986). The screening did not result in the isolation of single compounds but the authors suggested that the observed analgesic activity may be due to steroidal compounds the plant contains (Figure 1). 


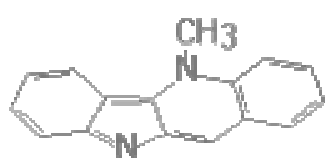

Cryptolepine

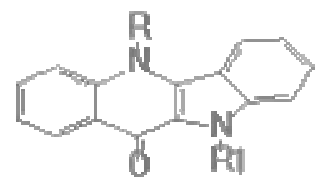

$\mathrm{R}=\mathrm{A1}: \mathrm{Or}$ indione $\mathrm{R}=\mathrm{CH} 3 \mathrm{Pi}=\mathrm{H}$ Cyptolephone

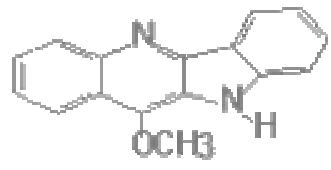

11-Metaxyqündaline<smiles>COC1CC(CCC(=O)NCCC2=CCC(O)CC2)CC=C1O</smiles><smiles>CC1(C)CC(=O)C[C@](C)(O)C1C=CC(O)C1CCCCC1</smiles><smiles>CC12CC(=O)OC(C)(CC(O)C1)C2</smiles>

Lifinte<smiles>COc1cc(C2OC(=O)C34COC(C5CCC(O)C(OC)C5)C2C3OC4)ccc1O</smiles><smiles>COC1C=C([C@H](C)C(C)O)CCC1O</smiles>

Evưoln-A

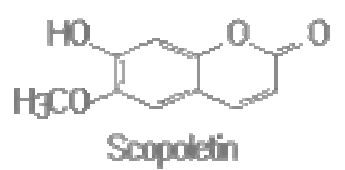

Scopolltin<smiles>COC1=C(O)CC[C@H](C(=O)C(CO)C2=CC[C@H](O)[C@H](O)C2)C1</smiles>

Evidin - B

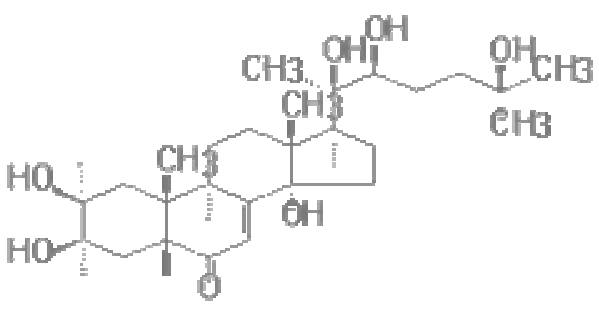

Ecdysterone

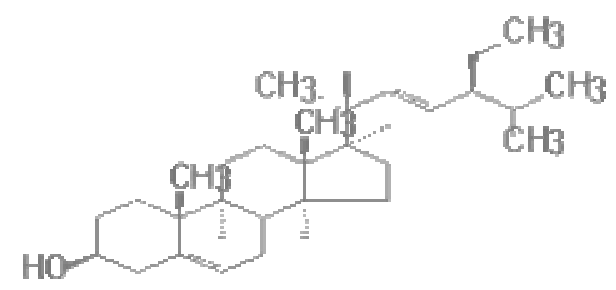

Stignasterol

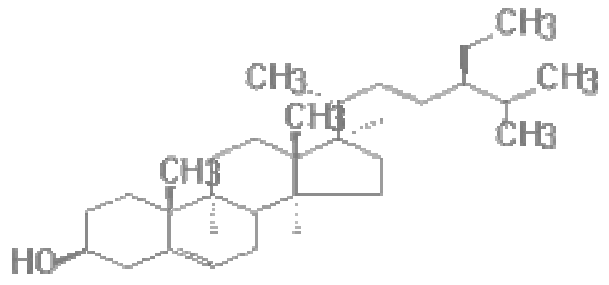

Betasistosterol

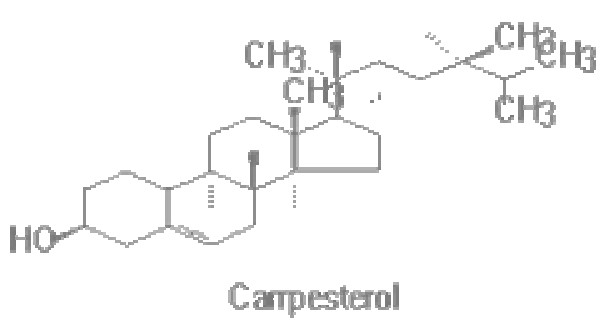

Figure 1. Chemical structure of compounds isolated from S. acuta. 


\section{PHARMACOLOGICAL PROPERTIES OF TWO SINGLE COMPOUNDS ISOLATED FROM S. ACUTA: CRYPTOLEPINE AND SCOPOLETIN}

\section{Cryptolepine}

Cryptolepine (5-methyl indolo [2,3b]-quinoline) is a natural alkaloid occurring in $S$. acuta, that was first isolated from the roots of Cryptolepis triangularis. This compound is the main alkaloid present in the roots of Cryptolepis sanguinolenta, a plant traditionally used in Central and West Africa for the treatment of rheumatism, urinary and respiratory infections. Cryptolepine presents a large spectrum of biological properties, including hypotensive and antipyretic, antimuscarinic, antibacterial and anti-inflammatory effects (Bonjean et al., 1998). It also possesses potent in vitro activity against $P$. falciparum, the main parasite species responsible for malaria. The mechanism of action of this antimalarial product remains unclear; at least two independent effects may together lead to a potent activity. First, it behaves like a DNA intercalator (Bonjean et al., 1998). Second, it may act like chloroquine by inhibiting the detoxification of heame in red blood cells (Wright et al., 2001). This is supported by a fluorescent microscopy study, which suggested that cryptolepine accumulates into parasite structures that may correspond to the parasite nucleus (Arzel et al., 2001). However, cryptolepine failed to cure malaria in mice by oral route, by intra peritoneal injection the compound showed toxic effects. These observations led to the investigation of its synthetic analogues such as 2,7-dibromocryptolepine (Wright, 2005).

It has been proposed that crytolepine exerts its cytotoxic action via the inhibition of DNA synthesis and stabilization of topoisomerase II-DNA covalent complexes. In a study conducted to elucidate the strength and mode of binding to DNA of cryptolepine and two other alkaloids by spectroscopy, Dassonneville et al. (1999) found that the alkaloid binds tightly to DNA and behaves as typical intercalating agent, thus it stabilizes the topoisomerase II-DNA covalent complex and stimulates the cutting of DNA by topoisomerase II, but the drug does not exhibit a preference for cutting at a specific base. However, the flow cytometry analysis showed that the drug alters the cell cycle distribution, but no sign of drug-induced apoptosis was detected when evaluating the internucleosomal fragmentation of DNA in cells. The authors suggested that cryptolepine-treated cells probably die via necrosis rather than via apoptosis and there was evidence that DNA and topoisomerase II are the primary targets of cryptolepine. In another study, the same authors found later that Cryptolepine induce apoptosis in $\mathrm{HL}_{60}$ leukaemia cells (Dassonneville et al., 2000). Recently, the structure of a cryptolepine-DNA complex was elucidated by X-ray crystallography. Lisgarten et al. (2002) demonstrated that the drug interacts with the $C C$ sites of the $d(C C T A G G) 2$ oligonucleotide.

\section{Scopoletin}

Scopoletin (6-methoxy-7-hydroxycoumarin) is a coumarin that has been isolated from many plants species. The compound has been tested for many pharmacological properties, we list below few examples of the described properties of the compound. Yang et al. (2007) observed that the compound significantly increased lipoprotein lipase activity 3T3-L1 adipocytes in dose- and timedependent manners. Scopoletin did not release the enzyme from the adipocyte membrane and, instead, decreased the enzyme mRNA level, suggesting a post transcriptional control. In the same study the compound was also found to partially reverse tumor necrosis factoralpha-induced suppression of lipoprotein lipase activity, thus the compound may act as a facilitator of plasma triglyceride clearance. Looking for the possible mode of action of scopoletin in the inflammatory cytokine production using CCRF-CEM leukemia cells, Moon et al. (2007) found that scopoletin was a potential regulatory of inflammatory reactions mediated by mast cells. Scopoletin was also found to inhibit leukemia cell proliferation. Tested against multidrug resistant subline CEM/ADR5000 cells together with standard cytostatic drugs, doxorubicin, vincristin and paclitaxel the cells did not exhibit cross resistance to the compound in contrast with what was observed with the standard drugs (Adams et al., 2006). However the compound was also found to exert a cytotoxic effect on tumoral lymphocytes (Manuele et al., 2006). Finally, scopoletin was found to inhibit the thyroid function and hyperglycemia without hepatotoxicity according to the study conducted by Panda and Kar (2006).

\section{CONCLUDING REMARKS}

S. acuta is a plant of wide usage in traditional medicine. Following these traditional usages many studies have been conducted in laboratories for the efficiency of the plant. It is now evident that the plant has a good antiplasmodial activity due to its alkaloids principally cryptolepine the main alkaloid of the plant. It is also demonstrated that the plant is active on several bacterial strains. Many other compounds which are demonstrated to have interesting pharmacological properties alone have been isolated from the plant, in addition the plant may have many other properties since it has not been tested for all desired pharmacological activities. However it should be noted that all laboratory screenings have been carried out with laboratory classical extractions as it is often observed with other medicinal plants. No study has been conducted with traditional preparation; this must be the priority for two reasons. First people still use the plant even if laboratory screenings do not confirm the assumed activity, so the laboratory results in the conditions of the traditional usage is more pertinent and can directly improve this usage. Secondly most of theses 
extracts act sometimes by synergistic effects so the fractionation may result in the lost of the activity, in addition the establishment of the drug from pure single compound may be too expensive so the drug may not be affordable for our populations.

\section{REFERENCES}

Adams M, Efferth T, Bauer R (2006). Activity guided isolation of scopoletin and isoscopoletin, the inhibitory active principles towards CCRF-CEM leukemia cells and multidrug resistant CEM/ADR5000 cells, from Artemisia argyi. Plant. Med. 72: 862-864.

Anani K, Hudson JB, De Souza C, Akpkagana K, Tower GHN, Amason JT, Gbeassor M (2000). Investigation of medicinal plants of Togo for antiviral and antimicrobial activities. Pharm. Biol. 38: 40-45.

Arzel E, Rocca P, Grellier P, Labaeid M, Frappier F, Gueritte F, Gaspard C, Marsais F, Godard A, Queguiner G (2001). New synthesis of benzo-delta-carbolines, cryptolepines, and their salts: in vitro cytotoxic, antiplasmodial, and antitrypanosomal activities of delta-carbolines, benzo-delta-carbolines, and cryptolepines. J. Med. Chem. 44: 949-960.

Banzouzi J-T, Prado R, Menan H, Valentin A, Roumestan C, Mallie M, Pelissier Y, Blache $Y$ (2004). Studies on medicinal plants of Ivory Coast: investigation of Sida acuta for in vitro antiplasmodial activities and identification of an active constituent. Phytomedicine 11: 338341.

Bonjean K, De Pauw-Guillet M-C, Defresne M-P, Colson P, Houssier C, Dassonneville L, Bailly C, Greimers R, Wright C, Quetin-Leclerck J, Tits $M$, Angenot $L$ (1998). The DNA intercalating alkaloid cryptolepine interferes with topoisomerase $\mathrm{II}$ and inhibits to primarily DNA synthesis in B16 melanoma cells. Biochemistry 37: 5136-5146.

Caceres A, Giron LM, Martinez AM (1987). Diuretic activity of plants used for the treatment of urinary ailments in Guatemala. J. Ethnopharmacol. 19: 233-245.

Cao JH, Qi YP (1993). Studies on the chemical constituents of the herb huanghuaren (Sida acuta Burm. f.) Zhongguo Zhong Yao Za Zhi. 18: 681-682.

Coee FG, Anderson GJ (1996). Ethnobotany in the Garifuna of Eastern Nicaragua. Econ. Bot. 50: 71-107.

Dash B (1991). Materia Medica of Ayurveda Based on Madanapala's Nighantu. B. Jain Publishers, New Delhi, p. 780.

Dassonneville L, Bonjean K, De Pauw-Gillet M-C, Colson P, Houssier C, Quetin-Leclercq JI, Angenot L, Bailly C (1999). Stimulation of Topoisomerase II-Mediated DNA Cleavage by Three DNAIntercalating Plant Alkaloids: Cryptolepine, Matadine, and Serpentine. Biochemistry 38: 7719-7726.

Dassonneville L, Lansiaux A, Wattelet A, Wattez N, Mathieu C, Van Miert S, Pieters L, Bailly G (2000). Cytotoxicity and cell cycle effects of the plant alkaloids cryptolepine and neocryptolepine: relation to drug-induced apoptosis. Eur. J. Pharmacol. 409: 9-19.

Desjardin RE, Canfield CJ, Haynes JD, Chulay JD (1979) Quantitative assessment of antimalarial activity in vitro by a semi automated microdilution technique. Antimicrob. Agents Chemother. 16: 710-718.

Dinan L, Bourne P, Whiting P (2001). Phytoecdysteroid profiles in seeds of Sida spp. (Malvaceae). Phytochem. Anal. 12: 110-119.

Dykstra LA, Woods JH (1986). A tail withdrawal procedure for assessing analgesic activity in rhesus monkeys. J. Pharmacol. Methods 15: 263-269.

Edeoga HO, Okwu DE, Mbaebie BO (2005). Phytochemical constituents of some Nigerian medicinal plants. Afr. J. Biotechnol. 4: 685-688.

Field JA, Lettinga G (1992). Toxicity of tannic compounds to microorganisms. Plants Polyphenols: Synthesis, Properties, Significance. Basic Life Sci. 59: 673-692.

Holm LG, Plucknett DL, Pancho JV, Herberger JP (1977). The Worlds Worst Weeds: distribution and biology.- University Press of Hawaii, Honolulu, USA.

Ignacimuthu S, Ayyanar M, Sankara-Sivaramann K (2006). Ethnobotanical investigations among tribes in Madurai District of Tamil Nadu (India). J. Ethnobiol. Ethnomed. 2: 25.
Jang DS, Park EJ, Kang YH, Su BN, Hawthorne ME, Vigo JS, Graham JG, Cabieses F, Fong HH, Mehta RG, Pezzuto JM, Kinghorn AD (2003). Compounds obtained from Sida acuta with the potential to induce quinone reductase and to inhibit 7,12dimethylbenz[a]anthracene-induced preneoplastic lesions in a mouse mammary organ culture model. Arch. Pharmacol. Res. 26: 585-590.

Karou D, Dicko MH, Sanon S, Simpore J, Traore SA (2003). Antimalarial activity of Sida acuta BURMF L. (Malvaceae) and Pterocarpus erinaceus POIR (Fabaceae) J. Ethnopharmacol. 89: 291-294.

Karou D, Dicko MH, Simpore J, Traore AS (2005). Antioxidant and antibacterial activities of polyphenols from ethnomedicinal plants of Burkina Faso. Afr. J. Biotechnol. 4: 823-828.

Karou D, Nadembega WMC, Ouattara L, ,llboudo DP, Canini A, Nikiéma JB, Simpore J, Colizzi V, Traore AS (2007). African ethnopharmacology and new drug discovery. Med. Aromatic Plant Sci. Biotechnol. 1: 61-69.

Karou D, Savadogo A, Canini A, Yameogo S, Montesano C, Simpore J, Colizzi V, Traore AS (2006). Antibacterial activity of alkaloids from Sida acuta. Afr. J. Biotechnol. 5: 195-200.

Kayode $J$ (2006). Conservation of indigenous medicinal botanicals in Ekiti State, Nigeria. J. Zhejiang University Sci. B 7: 713-718.

Kerharo J, Adam JG (1974). La pharmacopée sénégalaise traditionnelle: plantes médicinales et toxiques. Ed Vigot frères Paris ISBN 2 - $7114-0646$ - 6.

Le Bras J, Deloron P (1983). In vitro study of drug sensitivity of Plasmodium falciparum: evaluation of a new semi-microtest. Am. J. Trop. Med. Hyg. 274: 14218-14223.

Lisgarten JN, Coll M, Portugal J, Wright CW, Aymami J (2002). The antimalarial and cytotoxic drug cryptolepine intercalates into DNA at cytosine-cytosine sites. Nat. Struct. Biol. 9: 57-60.

Malairajan P, Gopalakrishnan G, Narasimhan S, Veni KJK (2006). Analgesic activity of some Indian medicinal plants. J. Ethnopharmacol. 106: 425-428.

Mann A, Gbate M, Umar AN (2003). Sida acuta subspecie acuta. Medicinal and economic palnt of Nupeland, Jube Evans Books and Publication, p. 241.

Manuele MG, Ferraro G, Barreiro Arcos ML, López P, Cremaschi G, Anesini C (2006). Comparative immunomodulatory effect of scopoletin on tumoral and normal lymphocytes. Life Sci. 79: 20432048.

Moon PD, Lee BH, Jeong HJ, An HJ, Park SJ, Kim HR, Ko SG, Um JY, Hong SH, Kim HM (2007). Use of scopoletin to inhbit the production of inflammatory cytokine through inhibition of Ikappa B/NF-Kappa Bsignal cascade in the human mast cell line HMC-1. Eur. J. Pharmacol. 555: 218-225

Nacoulma/Ouédraogo OG (1996). Plantes médicinales et pratiques médicales traditionnelles au Burkina Faso. Cas du plateau central Mossi Thèse d'Etat. Université de Ouagadougou.

National Committee for Clinical Laboratory Standards (NCCLS) (2000). Methods for dilution, antimicrobial susceptibility tests for bacteria that grow aerobically, $5^{\text {th }}$ edition volume 17 . Approved standards-M7-A4. NCCLS document M7-A4. National Committee for Clinical Laboratory Standard Wayen $\mathrm{Pa}$.

Orech FO, Akenga T, Ochora J, Friis H, Aagaard-Hansen J (2005). Potential toxicity of some traditional leafy vegetables consumed in nyang'oma division, western Kenya. Afr. J. Food Nutr. Sci. 5: 1-13.

Otero R, Nunez V, Barona J, Fonnegra R, Jimenez SL, Osorio RG, Saldarriaga M, Diaz A (2000). Snakebites and ethnobotany in the northwest region of Colombia. Part III: neutralization of the haemorrhagic effect of Bothrops atrox venom. J. Ethnopharmacol. 73: 233-241.

Otero R, Núñez V, Jiménez SL, Fonnegra R, Osorio RG, García ME, Díaz A (2000) Snakebites and ethnobotany in northwest region of Colombia Part II: Neutralization of lethal and enzymatic effects of Bothrops atrox venom. J. Ethnopharmacol. 71: 505-511.

Pakia M (2005). African Traditional Plant Knowledge Today: An Ethnobotanical Study of the Digo at the Kenya Coast. Doctorate Thesis, University of Bayreuth Germany

Pal DC, Jain SK (1998). Tribal Medicine. Naya Proska, Calcutta, India, p. 317.

Panda S, Kar A (2006). Evaluation of antithyroid, antioxidative and antihyperglycemic activity of scopoletin from Aegle marmelos leaves 
in hyperthyroid rats. Phytother. Res. 20: 1103-1105.

Perez C, Pauli M, Bazerque P (1990). An antibiotic assay by the agarwell diffusion method. Acta Biol. Med. Exp. 15: 113-115.

Prieto P, Pineda M, Aguilar M (1999). Spectrophotometric quantification of antioxidant capacity through the formation of a phosphomolybdenum complex: specific application of vitamin $\mathrm{E}$ analytical. Biochemistry 269: 337-341.

Rajakaruna N, Haris CS, Towers GHN (2002). Antimicrobial activity of plants collected from serpentine outcrops in Sri Lanka. Pharm. Biol. 40: 235-244.

Re R, Pellegrini N, Proteggente A, Pannala A, Yang M, Rice-Evans C (1999). Antioxidant activity applying an improved ABTS radical cation decolorization assay. Free Radical Biol. Med. 26: 1231-1237.

Saganuwan AS, Gulumbe ML (2006) Evaluation of Sida acuta subspecie acuta leaf/flower combination for antimicrobial activity and phytochemical constituents. Afr. J. Clin. Exp. Microbiol. 7: 83-88.

Scalbert A (1991). Antimicrobial properties of tannins. Phytochemistry 30: $3875-3883$

Scalbert A (1992). Quantitative methods for the estimation tannins in plants tissues. Plants Polyphenols: Synthesis, Properties, Significance. Basic Life Sci. 59: 673-692.

Schulze DLC, Makgatho EM, Coetzer TL, Louw Al, Van Rensburg CEJ, Visser L, (1997). Development and application of a modified flow cytometry procedure for rapid in vitro quantification of malaria parasitemia. S. Afr. J. Sci. 93: 156-158.
Singleton VL, Orthofer R, Lamuela-Raventos RM (1999). Analysis of total phenols and oxidization substrates and antioxidants by means of Folin-Ciocalteu reagent. Methods Enzymol. 299: 152-177.

Woolfe G, Mac Donald AD (1944). The evaluation of analgesic action of pethidine hydrochloride (DEMEROL). J. Pharmacol. Exp. Ther. 80: 300-307.

Wright CW (2005). Traditional antimalarials and the development of novel antimalarial drugs. J. Ethnopharmacol. 100: 67-71.

Wright CW, Addade-Kyereme J, Breen AG, Brown JE, Cox MF, Croft SL, Gokcek Y, Kendrick H, Phillips RM, Pollet ML (2001). Synthesis and evaluation of cryptolepine analogues for their potential as new antimalarial agents. J. Med. Chem 44: 3187-3194.

Yang JY, Koo JH, Lee JH, Park BH, Kim JS, Chi MS, Park JW (2007). Effect of scopoletin on lipoprotein lipase activity in 3T3-L1 adipocytes. Int. J. Mol. Med. 20: 527-231. 